\title{
LEARNING SCIENCE ONLINE: A DESCRIPTIVE STUDY OF ONLINE SCIENCE COURSES FOR TEACHERS
}

\author{
Jodi Asbell-Clarke and Elizabeth Rowe \\ TERC
}

\begin{abstract}
Online education is a rapidly growing phenomenon for science teachers. Using a sample of 40 online science courses for teachers offered during the 2004-2005 academic year, the Learning Science Online (LSO) study examines the nature and variety of instructional methods and activities as well as communication, and students' perceptions of supports within the course. This research is unique in that it is the first aggregate study of online science courses offered by a wide variety of educational programs. Descriptive analyses suggest the instructional methods employed in online science courses for teachers include frequent use of online discussions and students participated in minds-on activities, including articulation and reflection on their scientific ideas, posing questions, analyzing data, and drawing conclusions from evidence. Hands-on instructional activities were rarely used, and pen-and-paper and collaborative instructional activities were occasionally used. Technology was used primarily for communications such as discussion boards, email, and chat, but there were very few other computerbased tools used within the courses. Students felt supported by instructors, other students, and the course design.
\end{abstract}

\section{KEYWORDS}

Science Education, Online Learning, Asynchronous Learning, Teacher Professional Development

\section{INTRODUCTION}

Online education is a rapidly growing industry [1, 2, 3] that suits the needs of many teachers by addressing issues of geographical remoteness, limited offerings by institutions, and their complex lives [4]. The teacher professional development community discovered early that online programs could offer "anytime, anywhere" education for working science teachers [5], and today there are entire master's degree programs online for science teachers. Teachers take these courses not only to improve their content knowledge, but also for professional certification and advancement. There are relatively few studies examining online science learning [6] and none to date that have examined more than a few courses.

Beginning in 2004, the Learning Science Online project has studied 40 online science courses designed for teachers to ask questions about (a) who takes online courses for teachers, (b) who teaches them, (c) who delivers them, and (d) what does teaching and learning look like in these courses as well as (e) what characteristics of these courses correlate with student performance. This paper focuses on the nature of teaching and learning in these courses. 


\section{REVIEW OF RELEVANT LITERATURE}

LSO builds upon research in science education, teacher professional development, and online learning. At the intersection of these fields lies a wealth of interesting questions about instructional methods, communication, and supports for students.

\section{A. Instructional Methods}

As education moves to an online environment, some traditional methods of instruction may be jeopardized by lack of immediacy with the instructor and students. Faculty may begin online science education with the idea that if they place their notes online and have a mechanism to exchange problem sets and exams with students that students will learn effectively [7]. Alternatively, a large body of literature describes online learning environments as conducive to different types of learning strategies such as critical thinking, reflection, and active participation $[8,9,10,11]$ and typically rooted in social constructivist learning theories [12]. Social constructivism also is the premise of many of the core principles for science teacher professional development outlined in the national standards [13] and driving research on science teacher professional development [14]. These learning principles promote science teacher professional development that immerses teachers as students within a community of scientific inquiry where they actively investigate phenomena that can be studied scientifically, interpreting results and making sense of findings consistent with currently accepted scientific understanding. They state that these experiences should also incorporate ongoing reflection on the process and outcomes of understanding science through inquiry, and encourage and support teachers in efforts to collaborate [13].

As learners of science engage in a community of scientific inquiry, students must articulate their ideas, defend them with evidence, and provide reasoning for the ongoing changes in their mental models [15]. Asynchronous discussion boards may provide unique opportunities for scientific inquiry due to their textbased, asynchronous, and archivable nature. Written discussion forces students to make their thinking visible to themselves, as well as others, which raises students' level of interaction with the content at hand. In addition, students' writing is typically available for review long after the time of posting, so it becomes a source of reflection or referral for the learner and others. The asynchronous nature of discussion boards builds in natural "wait-time”. Learners can respond to questions or comments whenever they are comfortable in doing so and can pace themselves as they read other students' ideas before articulating their own. This built in wait time has been suggested as a benefit of online learning that allows participants the opportunity to provide a thoughtful response to questions [16].

Laboratory instruction has been a particular question for online science education. America's Lab Report [17] explains that the effectiveness of even face-to-face laboratory instruction on learning is not well known because of lack of meta-studies of any significance, so they strongly call for more research including the use of emerging technologies in this area. A study of a virtual chemistry laboratory program [18] used with undergraduates show that a majority of the students felt that an online lab in organic chemistry allowed them to focus on the "why" of the actual chemistry rather than the instructions to perform techniques. In this same study, however, a majority of students reported that they did not learn any chemistry from completing the assignments used in the online lab environment, reporting instead that all of their chemistry knowledge came from in-person laboratory experiences. A study of an online master's program in science education [19] compared an online course to an analogous face-to-face course to study the frequency of students' reflections on their own learning process, teaching strategies, and the nature of the science content learned. These students frequently partook in hands-on "kitchen" experiments, before which they made predictions and then asked to articulate, reflect, and revise their theories as they gathered evidence through their experimentation. The analysis of online asynchronous 
discussions and videotape of analogous classroom discussions showed that the online participants demonstrated more reflection and articulation about their own science learning and the process of inquiry than did their on-campus counterparts. This study also found a greater change in science understanding (as measured through pre- and post- thought experiments) in the online participants, and they were shown to have more confidence in teaching inquiry than the on-campus participants did.

\section{B. Communication}

The nature of communication in online learning environments may be very different than face to face environments, as has been shown in many settings as computer mediated communication (CMC) has replaced face-to-face contact. The lack of social context cues in e-mail in some settings has been shown to lead to uninhibited communication such as hostile and intense language (i.e., flaming), greater selfabsorption, and a resistance to defer speaking turns to higher-status participants [20]. In other CMC studies, users rated text-based media, including e-mail and computer conferencing, as equally rich or richer than telephone conversations and face-to-face conversations [21]. The asynchronicity of discussion boards is argued to be an important factor in metacognition for learners in online environments. Because a student may take their time to digest a question and formulate a response, and those responses are archived for later viewing, it is believed that this may promote reflection and thus deepen the learning [22].

Communication plays a key role in many online learning theories that tend toward social constructivism, where emphasis is placed on student interactions within a group rather than an instructor-led learning experience. The lack of visual cues such as seating arrangements and eye-contact provide a different quality to the social and teaching presence $[23,24]$ within a class, which may encourage students to take more or less of a lead in their own learning. Evidence of such a shift in roles might be found in online discussions, if students have more of a role in choosing topics for discussion and participate frequently in the discussions themselves. The participation of many students in communication may be an indicator of a learning environment where students take an active role in their learning, while discussions which are dominated by the instructor or only a few students may indicate that there are many passive students in the course who may or may not be engaged in learning. The amount of interactivity, or quantity and quality of interactions, in online discussions has been shown to correlate positively with performance on written assignments for the course [25]. The same study cautions that students' perceptions of their level of interactivity was not a good predictor of students actual participation.

\section{Perceived Support}

Students' perceptions about the support they receive from the instructor, other students, and the course environment itself may affect their participation in the course and thus potentially affect their learning. Within rich learning environments, students may benefit from many levels of support, particularly if there is coherence among the supports from course materials, instructor facilitation, and a peer group or learning community.

Course design takes on a whole new meaning in online education. As opposed to a face-to-face instructor, who has the option of waiting until the night before to prepare lecture notes or possibly "winging it" once they arrive at class, an online instructor typically must design and develop materials all in advance so that they are available from the beginning of the course. This may, as a fortunate by-product, force some overall course coherence and structure into the course design. Online courses may also distinguish the role of instructional designer from that of facilitator and have two (or more) different people do the two tasks. Online course design involves designing instructional methods and organizing materials to help 
students make meaning from the course content, allowing sufficient time for and placing high priority on online discussions and interactions, building a sense of community among students, and generally setting a climate for learning [26, 27].

The course designer and/or instructor also typically choose the types of learning tools used in the course. The very existence of many online science courses for teachers is a testament to the rapid adoption of many new technologies, some of which may provide new ways to enhance students' construction of conceptual knowledge. Tools often associated with online course environments include email, asynchronous discussion boards, synchronous chat rooms, assignment dropboxes (sometimes with feedback areas), grading books, calendars, and sometimes whiteboards or other graphic sharing tools. Generally speaking, web-based courses also may easily link to external web learning objects such as computer simulations, visualization software, and interactives. Some of these tools have been unexploited because of high-speed connectivity issues for many users, but as broadband Internet usage soars [28], designers will have a suite of tools to choose from, in order to make the most appropriate learning environment for the task at hand.

The role of the instructor has always been of question in distance education. Early models that adopted traditional designs for learning had students working on their own with instructors responding only when they were asked for help [29]. Most current online learning models are based upon a strong belief that the presence of an instructor is tremendously important to the learning experience, either face-to-face or online, but with different roles. In online learning, an instructor is seen as more of a facilitator who guides student learning using strategies such as open-ended questions and summarizing comments from messages posted in a discussion [8]. Instructors are seen as vital to synthesizing distributed knowledge and guiding groups toward deeper insights [30] as well as knowing when to push individuals and groups further and when to step in to offer help to participants in constructing new knowledge [31]. An increasing number of studies show that instructors' behaviors of immediacy, such as using humor to break the ice, providing and inviting feedback from students, and addressing students directly by name, all help to provide a presence that is positively associated with student learning and satisfaction [32, 33]. It has also been noted [34] that faculty who choose to teach asynchronously tend to value their students as lifelong learners and value learning as an active, constructive process that depends on teamwork and cooperation. In a model of a community of inquiry often used in online settings, direct instruction is also stated to play a role [35]. This model describes teaching presence as a combination of course design, facilitation, and direct instruction. The skilled online instructor not only knows how do each of these well, but provides a sense of balance and coherence among them.

A number of studies have shown the perception of interpersonal connections with peers to be an important factor in the success of online learning [36-40]. Social interaction provides opportunities to make internal thought processes public, or make thinking visible, which is seen as a prerequisite for knowledge building [41]. In a social learning environment, where knowledge is constructed as part of a group, the support of other students in the group is vital to encourage learners to take risks, pose questions, ask for clarification, and share their ideas with the group. In studies of online professional development seminars for math teachers, a sense of community was found to be important to participants, as participants appreciated being part of a group of colleagues with similar interests, having a support system, and reading other students' ideas [42]. Some have suggested a sense of "hyperpersonalness" of online discussion [21]. Students enrolled in an online graduate course in education were asked about their perceived social presence, or sense of belonging, and those data were compared with their performance on tests and written assignments. While there were no significant differences between groups with different levels of social presence on test scores, the group reporting higher social presence scored higher on written assignments than those in the lower social presence group [25]. 


\section{RESEARCH QUESTIONS}

There is a large body of literature that suggests online learning environments are well-suited to social constructivist learning environments, or communities of scientific inquiry, as called for by the national standards in professional development for science teachers. Research shows, however, that many novice online course developers have major misconceptions about the pedagogy that produces effective online learning [43]. This is not surprising since so little is known about online practices on a large scale, and in particular in science learning online.

Some instructors still believe that delivering an online course just means replicated course notes and exams online [7]. The developers of online learning software, on the other hand, advertise many features within their products such as data sharing tools and whiteboards, libraries of learning modules, and even immersion experiences within virtual worlds. As online learning becomes a stronger presence in the educational arena, more research is needed to understand the nature of how the technology is being used and which tools are more or less conducive to learning. The communication and supports within an online course become central to the climate of the course. When students perceive a safe and friendly environment, they will become more active participants in their own learning [8]. Understanding the extent to which students perceived support from their instructors, other students, and the course design will provide a picture of the climate within each course and how it describes a model that may be conducive to the social construction of knowledge. Examining the dynamics and nature of the communication within the course will enable us to search for evidence of changing (or unchanging) roles between students and instructors as well as look for conditions believed to be conducive to social construction of knowledge.

In order to understand how online environments are actually being used to deliver science courses for teachers, LSO has asked:

- What types of instructional methods are used in online science courses for teachers?

- What is the nature of communication between students and instructors in online science courses for teachers?

- What is the extent of support perceived by students from their instructors, other students, and the course environment?

\section{METHODOLOGY}

Learning Science Online (LSO) is a mixed-method longitudinal study of 40 online science courses for K12 teachers offered during the 2004-2005 academic year. LSO collected data from three types of participants: program coordinators at institutions offering courses, course instructors, and students. Participants at all levels were informed that the purpose of this study was to learn about the nature of all online science courses for teachers rather than the evaluation of their specific course.

\section{A. Courses}

To ensure a sufficient level of uniformity, courses were sought that met the following criteria:

- At least one graduate credit is offered for the course;

- Science content is the primary focus of the course (as opposed to instructional methods);

- Course requires some interaction among students and between instructor and students, which occurs primarily, but not necessarily exclusively, online via discussion boards, e-mail, chat 
rooms, or other electronic media (excluding TV monitors).

Of the 60 courses we found meeting these criteria, 45 participated in the study and 40 of those were unique course (five were courses that were re-offered for a second time within the study period), giving an overall participation rate of 75 percent.

Six programs hosted the online courses in this study. Three programs were administered by educational nonprofit institutions and the other three were administered by universities - either within an academic department or through a continuing education or distance education program. Courses in any of these programs may have contributed to a master's degree, but only two programs offered online master's degrees themselves. Courses are described in terms of their duration, credits offered, content areas, affiliation with a master's degree program, and audience for the course in Table 1. The typical course in this study was a biology/life sciences course of 12-14 weeks in duration, offered for 3 graduate credits, affiliated with a master's degree program and designed specifically for high school science teachers. All except one course in this study was offered through a pre-existing online course platform-WebCT, Blackboard, or eCollege.

Two programs, one university and one nonprofit, are no longer offering the courses in this study. The remaining four programs vary in their level of self-sustainability. The online programs at the nonprofit institutions depend upon the support of their parent organization. At the universities, one online program is completely self-sustainable and profitable while the other is still supported through grants. 


\section{Course Characteristics}

\section{Number of Courses \\ Percentage of Courses}

Maximum Number of Credits

1 credits

2 credits

3 credits

4 credits

Affiliation with Masters program

Part of a Masters program

Independent of a Masters program

Content areas of course

Astronomy

Biology/Life Science

Chemistry

Earth/Space Science

Environmental Science

Physics

Science Education

Other

Audience of course

Elementary school

Middle school

High School

Unidentified level

Duration

5 weeks

6 weeks

12 weeks

14 weeks

16 weeks

17 weeks
$26 \quad 65 \%$

$14 \quad 35 \%$

$\begin{array}{cc}5 & 13 \% \\ 28 & 70 \% \\ 5 & 13 \% \\ 14 & 35 \% \\ 13 & 33 \% \\ 7 & 18 \% \\ 13 & 33 \% \\ 9 & 23 \%\end{array}$

$923 \%$

$18 \quad 45 \%$

$30 \quad 75 \%$
$7 \quad 18 \%$
$3 \%$

$23 \%$

$10 \%$ 


\section{B. Instructors}

Program coordinators identified the following criteria when selecting instructors for their courses: strong science background; K-12 teaching experience; teacher professional development experience; university teaching experience; and, to a lesser extent, publication record, schedule flexibility, and online teaching experience. Many instructors were selected from a pool of current and retired colleagues. None of the programs reported a formal recruitment process, although most said they had turned away unsolicited requests to teach online courses.

A total of 35 unique instructors participated in this study. Table 2 describes these instructors in terms of their gender, age, their highest degree earned, whether they taught the online course through a university or nonprofit institution, and their appointment at that institution. The typical instructor in this study was a 50-59 year old white male with a science Ph.D. teaching the online course through a university science department without a regular faculty appointment in that department. Over two-thirds of the instructors had earned a doctorate, with 88 percent of those degrees in a science field. The majority of the instructors with a bachelor's or master's degree as their highest degree were graduate students working toward higher degrees. More than twice as many instructors do not have regular faculty appointments (assistant, associate, full, or emeritus professor) as do have them, with instructors at universities more likely to hold regular faculty appointments than instructors at nonprofit institutions ( $\mathrm{t}=-4.71,24$ d.f., $\mathrm{p}<0.001$ ). Programs varied in how instructors are compensated and, in universities, whether online courses are considered part of their teaching load or as overload.

Instructors' experience specifically teaching online could influence the design and implementation of their courses. Most instructors had taught online prior to teaching their current courses, although a third of the instructors had taught only their current course online. Half of the instructors reported some type of formal facilitation training, with all of the nonprofit instructors $(n=10)$ and a third of the university instructors $(\mathrm{n}=7)$ reporting such training $(\mathrm{t}=-7.14,24$ d.f., $\mathrm{p}<0.0001)$. 


\begin{tabular}{|c|c|c|c|}
\hline \multirow[b]{2}{*}{ Instructor Characteristics } & \multicolumn{3}{|c|}{ Percentage of: } \\
\hline & $\begin{array}{c}\text { All } \\
\text { Instructors } \\
(\mathrm{n}=35)\end{array}$ & $\begin{array}{c}\text { Nonprofit } \\
\text { Instructors } \\
(\mathrm{n}=10)\end{array}$ & $\begin{array}{l}\text { University } \\
\text { Instructors } \\
\quad(n=25)\end{array}$ \\
\hline Male Instructors & $63 \%$ & $40 \%$ & $72 \%$ \\
\hline Caucasian & $97 \%$ & $90 \%$ & $100 \%$ \\
\hline \multicolumn{4}{|l|}{ Age } \\
\hline Less than 30 years old & $3 \%$ & $0 \%$ & $4 \%$ \\
\hline 30-39 years old & $14 \%$ & $30 \%$ & $8 \%$ \\
\hline 40-49 years old & $11 \%$ & $10 \%$ & $12 \%$ \\
\hline 50-59 years old & $40 \%$ & $20 \%$ & $48 \%$ \\
\hline $60-69$ years old & $23 \%$ & $20 \%$ & $24 \%$ \\
\hline 70-79 years old & $9 \%$ & $20 \%$ & $4 \%$ \\
\hline \multicolumn{4}{|l|}{ Highest Degree Earned } \\
\hline Bachelor's & $9 \%$ & $10 \%$ & $8 \%$ \\
\hline Master's & $23 \%$ & $60 \%$ & $8 \%$ \\
\hline Doctorate & $69 \%$ & $30 \%$ & $84 \%$ \\
\hline \multicolumn{4}{|l|}{ Type of appointment } \\
\hline No appointment at this institution & $23 \%$ & $50 \%$ & $12 \%$ \\
\hline Instructor/Lecturer & $26 \%$ & $40 \%$ & $20 \%$ \\
\hline Adjunct professor & $11 \%$ & $10 \%$ & $12 \%$ \\
\hline Assistant professor & $0 \%$ & $0 \%$ & $0 \%$ \\
\hline Associate professor & $17 \%$ & $0 \%$ & $24 \%$ \\
\hline Full professor & $9 \%$ & $0 \%$ & $12 \%$ \\
\hline Professor emeritus & $9 \%$ & $0 \%$ & $12 \%$ \\
\hline Other appointment & $6 \%$ & $0 \%$ & $8 \%$ \\
\hline Have regular faculty appointment & $26 \%$ & $0 \%$ & $36 \%$ \\
\hline
\end{tabular}

NOTE: Regular faculty appointments are the assistant, associate, full, and emeritus positions.

Table 2. Percentage of Instructors by Gender, Race, Age, Highest Degree Earned, Type of Appointment Overall and by Program Type

Instructors were asked to identify which of the following content areas were included in their course: (a) Astronomy; (b) Biological/Life Sciences; (c) Earth/Space Science; (d) Environmental Science; (e) Physics; (f) Science Education; and (g) Other science or education. Of interest here is the match between the educational background of the instructors and the science content of the courses they are teaching (see Table 3). 


\begin{tabular}{|c|c|c|c|c|c|}
\hline \multirow{2}{*}{$\begin{array}{l}\text { Content areas included in } \\
\text { course }\end{array}$} & \multirow{2}{*}{$\begin{array}{c}\text { Number } \\
\text { of } \\
\text { Courses }\end{array}$} & \multicolumn{4}{|c|}{$\begin{array}{c}\text { Percentage of courses taught by instructors with the } \\
\text { following degrees in that content area }\end{array}$} \\
\hline & & Bachelors & Masters & Doctorate & $\begin{array}{l}\text { No Degree in } \\
\text { Content Area }\end{array}$ \\
\hline Biology/Life Science & 31 & $65 \%$ & $45 \%$ & $45 \%$ & $19 \%$ \\
\hline Earth/Space Science & 15 & $20 \%$ & $7 \%$ & $20 \%$ & $73 \%$ \\
\hline Physics & 7 & $14 \%$ & $14 \%$ & $0 \%$ & $86 \%$ \\
\hline
\end{tabular}

NOTE: Percentages may not sum to 100 because participants were instructed to select all that apply. Biology/Life Science includes courses with content in biology/life science and environmental sciences. Earth/Space Science includes courses with content in astronomy and Earth/space science.

Table 3. Number and Percentage of Instructor Fields of Study by Content Area of the Course(s) they are Teaching in the Study

Out-of-field teaching was least common in the biological/life sciences and more common in earth/space sciences and physics. Eighty-one percent of the instructors teaching biology/life sciences courses had a degree in the biological sciences. The remaining $19 \%$ of instructors of biology/life science courses had degrees in chemistry, Earth/space sciences, or science education. Only four of the courses with Earth/space science content were taught by an instructor with a degree in that content area. Instructors with degrees in biological and life sciences taught seven of those other eleven courses. Seven courses with physics content were offered, with one instructor reporting a bachelor's and master's degree in physics. Half of the instructors of these courses had degrees in other science fields and half had degrees in science education.

\section{Students}

Of the almost 800 students enrolled in the 40 online science courses in this study, $90 \%$ completed their courses. Instructors reported 735 students were enrolled in these 40 courses at the end of the add-drop period-two-thirds of whom were female. Forty percent of the students in these courses $(n=296)$ completed the pre- and post-questionnaires as part of this study. While this student response rate is not ideal, it exceeds the response rate of other studies of online education [2]. Of the 296 students in this study, 46 students were taking more than one courses in this study. Student demographics are reported for the 250 unique students while course-specific data include all students.

The low student response rate suggests the perspectives of these students may be selective in unknown ways. One third of those students completing the pre- and post-questionnaires were male and two thirds were female. There was no difference in the student participation rates by gender in the study. Students who performed better in their courses were more likely to have participated in this study- $45 \%$ of those who received As completed pre- and post-questionnaires versus 39\% of those receiving Bs, $17 \%$ receiving Cs, and 7\% of those who failed, received an incomplete, or withdrew from the course. This suggests the data from students are more representative of those who performed well in their course than of those who did not.

Reflecting the institutions delivering these 40 online courses, almost two-thirds of the students ( $\mathrm{n}=156$ ) took their online course through a university program and one-third took their course through a nonprofit program ( $n=94)$. Table 4 describes demographic characteristics of these students. 


\begin{tabular}{|c|c|c|c|}
\hline \multirow[b]{2}{*}{ Student Characteristics } & \multicolumn{3}{|c|}{ Percentage of } \\
\hline & $\begin{array}{c}\text { All } \\
\text { Students } \\
(n=250)\end{array}$ & $\begin{array}{c}\text { Students in } \\
\text { nonprofit } \\
\text { courses } \\
(n=94) \\
\end{array}$ & $\begin{array}{c}\text { Students in } \\
\text { university } \\
\text { courses } \\
(\mathrm{n}=156) \\
\end{array}$ \\
\hline Female Students & $64 \%$ & $71 \%$ & $60 \%$ \\
\hline \multicolumn{4}{|l|}{ Race } \\
\hline Asian & $1 \%$ & $0 \%$ & $2 \%$ \\
\hline Black or African-American & $4 \%$ & $4 \%$ & $4 \%$ \\
\hline Hispanic or Latino & $1 \%$ & $2 \%$ & $1 \%$ \\
\hline White & $91 \%$ & $90 \%$ & $91 \%$ \\
\hline Not reported & $2 \%$ & $2 \%$ & $1 \%$ \\
\hline \multicolumn{4}{|l|}{ Age } \\
\hline 25-35 years & $25 \%$ & $20 \%$ & $28 \%$ \\
\hline $36-45$ years & $32 \%$ & $34 \%$ & $31 \%$ \\
\hline $46-55$ years & $24 \%$ & $21 \%$ & $26 \%$ \\
\hline 56-65 years & $17 \%$ & $21 \%$ & $14 \%$ \\
\hline $65+$ years & $1 \%$ & $3 \%$ & $0 \%$ \\
\hline Bachelor's Degree in Science & $66 \%$ & $57 \%$ & $71 \%$ \\
\hline \multicolumn{4}{|c|}{ 10+ Years Science Teaching Experience } \\
\hline Yes & $21 \%$ & $22 \%$ & $20 \%$ \\
\hline No & $62 \%$ & $63 \%$ & $62 \%$ \\
\hline Never taught & $17 \%$ & $15 \%$ & $18 \%$ \\
\hline
\end{tabular}

NOTE: Students who took more than one course are included once in this table with one exception--four students who took courses in two programs are counted twice.

Table 4. Percentage of Students by Gender, Race, Age, Whether or not they have a Bachelor's Degree in Science, and Whether or not they have more than 10 Years of Science Teaching Experience

The typical student in these online courses were white females with a bachelor's degree in a science field who were middle or high school science teachers with 10 or fewer years teaching experience. Students in university courses were significantly more likely to have earned a bachelor's degree in a science field than were students in nonprofit courses $\left(X^{2}=4.91,1\right.$ d.f., $\left.p=0.0267\right)$. Among the 296 students participating in this study, this was the first online course for a quarter of them $(n=72)$.

In summary, a total of 35 instructors and 250 unique students from 40 unique courses delivered by 6 institutions participated in this study.

\section{Data Sources}

Instructors' and students' pre- and post-course questionnaires were developed and tested with focus groups and piloted in four online courses during the summer of 2004. All questionnaires were administered online. Instructor and student pre-questionnaires collected demographic information such as 
their highest degree earned, fields of study, teaching experience, experience with online courses, and their expectations about the course.

To measure instructional methods employed in online science courses for teachers, we developed a set of survey items based on the measure of reform-based instruction in $\mathrm{K}-12$ science classrooms developed by Borko and her colleagues [44]. Although Borko's constructs were developed to examine children's learning, many of their principles are compatible with the call for new methods of professional development for teachers. This framework has many parallels to NSES standards [13]; it utilized detailed rubrics in classroom observations with moderate to high levels of inter-rater agreement. Constructs particularly relevant for measuring reform-based science instruction in online courses for teachers include:

- Hands-On: The extent to which learners are interacting with physical materials or models to learn science.

- Minds-On: The extent to which learners participate in activities that engage them in wrestling with scientific issues and developing their own understanding of scientific ideas.

- Collaborative Grouping: The extent to which a series of lessons uses learner groups to promote learning.

Questions about the use of common instructional methods for science (e.g., completing problem sets, reading textbooks) as well as those unique to online courses (e.g., online discussion boards, simulations) were also included so as to cover the potential range of instructional methods used in these courses. Instructors were asked about the frequency with which students were expected to participate in each instructional activity and their expected usage of specific instructional materials (e.g., books, web readings, calculators, images). In addition to questions about instructional methods and materials, instructor and student post-questionnaires focused on overall course characteristics such as:

- the perceived level of intellectual difficulty of course materials,

- the frequency and nature of assessment;

as well as the nature of communication and dynamics in the course, including:

- frequency and nature of communication between instructor and students,

- frequency and nature of communication among students,

- control and dynamics within online discussions,

- perceived level of support from instructor, other students, and course design.

These pre- and post-questionnaires are the primary data sources for this study. Interviews were also conducted with program coordinators to understand how instructors were recruited, hired, and compensated and to understand the position of the programs within the larger institutions in terms of support provided and self-sustainability.

\section{E. Data Analysis}

The descriptive analyses presented in this paper require comparisons of means and distributions of responses. Standard statistical tests such as t-tests and chi-square tests were used. In cases when a large number of statistical tests were used on the same variables, a Scheffe test was employed to control the amount of Type I error across the t-tests. Cronbach's alpha, a measure of internal consistency of a set of 
items, are reported for each of the instructional method's scales.

\section{RESULTS/FINDINGS}

The findings are organized around the central research questions about the nature of teaching and learning in these online science courses for teachers:

- What types of instructional methods are used in online science courses for teachers?

- What is the nature of communication between students and instructors in online science courses for teachers?

- What is the extent of support perceived by students from their instructors, other students, and the course environment?

\section{A. What Types of Instructional Methods are Used in Online Science Courses for Teachers?}

Instructors were asked how frequently they expected students to engage in 23 types of instructional activities and 11 types of instructional materials likely to be found in online science learning environments. Half of these items clustered into four constructs-(1) Pen-and-paper, (2) Hands-on, (3) Minds-on, and (4) Collaborative activities (see Tables 5-8 for specific items). The internal consistencies of all constructs ranged from alphas of 0.62 (pen and paper) to 0.87 (collaborative activities). The remaining 17 instructional activities did not cohere with any one of these constructs (see Table 9).

\section{Pen-and-Paper Instructional Methods}

Pen-and-paper methods, typical of direct instruction, were not absent from online courses, nor did they dominate the pedagogy. Table 5 shows that most instructors expected their students to occasionally engage with pen-and-paper instructional activities. The most common instructional materials used were hard-copy books, with half of the instructors expecting students to use them at least once a week. The least common pen-and-paper instructional material was calculator usage, with only 20 percent of instructors expecting students to use them at any time during the course.

\begin{tabular}{|c|c|c|c|c|c|c|}
\hline \multirow[b]{2}{*}{ Pen \& Paper Activities \& Materials } & \multicolumn{5}{|c|}{$\begin{array}{c}\text { Percentage and Number of Instructors Expecting } \\
\text { Students to Engage in the Activity or With Course } \\
\text { Materials }\end{array}$} & \multirow[b]{2}{*}{ Mear } \\
\hline & $\begin{array}{l}\text { Not at } \\
\text { All }\end{array}$ & $\begin{array}{l}\text { Once or } \\
\text { Twice During } \\
\text { the Course }\end{array}$ & $\begin{array}{l}\text { Once or } \\
\text { Twice a } \\
\text { Month }\end{array}$ & $\begin{array}{c}\text { Once or } \\
\text { Twice a } \\
\text { Week }\end{array}$ & $\begin{array}{c}\text { Three } \\
\text { Times a } \\
\text { Week or } \\
\text { More } \\
\end{array}$ & \\
\hline Books & $\begin{array}{l}33 \% \\
(13)\end{array}$ & $\begin{array}{l}10 \% \\
(4)\end{array}$ & $\begin{array}{l}3 \% \\
(1)\end{array}$ & $\begin{array}{l}35 \% \\
(14)\end{array}$ & $\begin{array}{l}20 \% \\
(8)\end{array}$ & 3.0 \\
\hline $\begin{array}{l}\text { Worked with pen and paper problem sets (e.g., } \\
\text { problems from a textbook or worksheet) }\end{array}$ & $\begin{array}{l}53 \% \\
(21)\end{array}$ & $\begin{array}{c}23 \% \\
(9)\end{array}$ & $\begin{array}{c}10 \% \\
(4)\end{array}$ & $\begin{array}{c}15 \% \\
(6)\end{array}$ & $\begin{array}{l}3 \% \\
(1)\end{array}$ & 2.0 \\
\hline Calculators & $\begin{array}{l}80 \% \\
(32)\end{array}$ & $\begin{array}{l}13 \% \\
(5)\end{array}$ & $\begin{array}{l}5 \% \\
(2)\end{array}$ & $\begin{array}{l}3 \% \\
(1)\end{array}$ & $\begin{array}{l}0 \% \\
(0)\end{array}$ & 1.3 \\
\hline
\end{tabular}

Table 5. Percentage and Number of Instructors Reporting on their Expectations for Student Engagement with Pen-and-paper Instructional Methods 


\section{Hands-on Instructional Methods}

Perhaps because of the amount of instructional time each hands-on activity requires or because they are typically done in group settings, most instructors rarely expected students to engage with hands-on instructional activities or materials in these online courses (see Table 6). Mean frequencies ranged from 1.6 to 1.9, suggesting that most students engaged with these activities at most once or twice during the course, if at all.

\begin{tabular}{|c|c|c|c|c|c|c|}
\hline \multirow{2}{*}{ Hands-on Activities \& Materials } & \multicolumn{5}{|c|}{$\begin{array}{c}\text { Percentage and Number of Instructors Expecting Students to } \\
\text { Engage in the Activity or With Course Materials }\end{array}$} & \multirow[b]{2}{*}{ Mean } \\
\hline & $\begin{array}{l}\text { Not at } \\
\text { All }\end{array}$ & $\begin{array}{l}\text { Once or Twice } \\
\text { During the } \\
\text { Course }\end{array}$ & $\begin{array}{l}\text { Once or } \\
\text { Twice a } \\
\text { Month }\end{array}$ & $\begin{array}{c}\text { Once or } \\
\text { Twice a } \\
\text { Week }\end{array}$ & $\begin{array}{l}\text { Three Times a } \\
\text { Week or More }\end{array}$ & \\
\hline $\begin{array}{l}\text { Designed their own scientific investigation(s) (e.g., } \\
\text { developed hypothesis or question and procedure }\end{array}$ & $\begin{array}{l}45 \% \\
(18)\end{array}$ & $\begin{array}{l}33 \% \\
(13)\end{array}$ & $\begin{array}{l}13 \% \\
(5)\end{array}$ & $\begin{array}{c}10 \% \\
(4)\end{array}$ & $\begin{array}{l}0 \% \\
(0)\end{array}$ & 1.9 \\
\hline $\begin{array}{l}\text { Carried out procedures of scientific investigations } \\
\text { designed by instructors or course developers (e.g., lab } \\
\text { exercises, kitchen experiments) }\end{array}$ & $\begin{array}{l}60 \% \\
(24)\end{array}$ & $\begin{array}{l}15 \% \\
(6)\end{array}$ & $\begin{array}{c}10 \% \\
(4)\end{array}$ & $\begin{array}{c}10 \% \\
(4)\end{array}$ & $\begin{array}{l}5 \% \\
(2)\end{array}$ & 1.9 \\
\hline $\begin{array}{l}\text { Interacted with physical materials or models (e.g., mixing } \\
\text { solutions, building circuits, scale models) }\end{array}$ & $\begin{array}{l}63 \% \\
(25)\end{array}$ & $\begin{array}{l}15 \% \\
(6)\end{array}$ & $\begin{array}{c}10 \% \\
(4)\end{array}$ & $\begin{array}{c}13 \% \\
(5)\end{array}$ & $\begin{array}{l}0 \% \\
(0)\end{array}$ & 1.7 \\
\hline $\begin{array}{l}\text { Carried out procedures of scientific investigations they } \\
\text { designed (e.g., collected data, made observations) }\end{array}$ & $\begin{array}{l}63 \% \\
(25)\end{array}$ & $\begin{array}{l}25 \% \\
(10)\end{array}$ & $\begin{array}{l}8 \% \\
(3)\end{array}$ & $\begin{array}{l}5 \% \\
(2)\end{array}$ & $\begin{array}{l}0 \% \\
(0)\end{array}$ & 1.6 \\
\hline
\end{tabular}

Table 6. Percentage and Number of Instructors Reporting on their Expectations for Student Engagement with Hands-on Instructional Activities and Materials

\section{Minds-on Instructional Methods}

As Table 7 reveals, these online science courses for teachers made frequent use of minds-on instructional activities, with the most common activity being articulating their scientific ideas in an online discussion (95 percent of instructors expecting this at least once a week). The least common minds-on activity was analyzing and drawing conclusions from data and observations, with an average frequency of once or twice a month. 


\begin{tabular}{|c|c|c|c|c|c|c|}
\hline \multirow{2}{*}{ Minds-on Activities \& Materials } & \multicolumn{5}{|c|}{$\begin{array}{c}\text { Percentage and Number of Instructors Expecting Students to } \\
\text { Engage in the Activity or With Course Materials }\end{array}$} & \multirow[b]{2}{*}{ Mean } \\
\hline & $\begin{array}{c}\text { Not at } \\
\text { All }\end{array}$ & $\begin{array}{l}\text { Once or Twice } \\
\text { During the } \\
\text { Course }\end{array}$ & $\begin{array}{l}\text { Once or } \\
\text { Twice a } \\
\text { Month }\end{array}$ & $\begin{array}{c}\text { Once or } \\
\text { Twice a } \\
\text { Week }\end{array}$ & $\begin{array}{l}\text { Three Times a } \\
\text { Week or More }\end{array}$ & \\
\hline $\begin{array}{l}\text { Articulated their scientific ideas in an online } \\
\text { discussion. }\end{array}$ & $\begin{array}{l}0 \% \\
(0)\end{array}$ & $\begin{array}{l}5 \% \\
(2)\end{array}$ & $\begin{array}{l}0 \% \\
(0)\end{array}$ & $\begin{array}{l}40 \% \\
(16)\end{array}$ & $\begin{array}{l}55 \% \\
(22)\end{array}$ & 4.5 \\
\hline Reflected upon the scientific ideas of other students. & $\begin{array}{l}0 \% \\
(0)\end{array}$ & $\begin{array}{l}3 \% \\
(1)\end{array}$ & $\begin{array}{c}10 \% \\
(4)\end{array}$ & $\begin{array}{l}53 \% \\
(21)\end{array}$ & $\begin{array}{l}35 \% \\
(14)\end{array}$ & 4.2 \\
\hline $\begin{array}{l}\text { Raised questions with other students about their } \\
\text { scientific ideas. }\end{array}$ & $\begin{array}{l}0 \% \\
(0)\end{array}$ & $\begin{array}{l}8 \% \\
(3)\end{array}$ & $\begin{array}{c}15 \% \\
(6)\end{array}$ & $\begin{array}{l}53 \% \\
(21)\end{array}$ & $\begin{array}{l}25 \% \\
(10)\end{array}$ & 4.0 \\
\hline Reflected upon their earlier scientific ideas & $\begin{array}{l}0 \% \\
(0)\end{array}$ & $\begin{array}{l}10 \% \\
(4)\end{array}$ & $\begin{array}{l}33 \% \\
(13)\end{array}$ & $\begin{array}{l}43 \% \\
(17)\end{array}$ & $\begin{array}{c}15 \% \\
(6)\end{array}$ & 3.6 \\
\hline Provided evidence to support their scientific ideas. & $\begin{array}{l}8 \% \\
(3)\end{array}$ & $\begin{array}{c}10 \% \\
(4)\end{array}$ & $\begin{array}{c}20 \% \\
(8)\end{array}$ & $\begin{array}{l}50 \% \\
(20)\end{array}$ & $\begin{array}{c}13 \% \\
(5)\end{array}$ & 3.5 \\
\hline $\begin{array}{l}\text { Analyzed and drew conclusions from data, } \\
\text { observations, and other forms of scientific evidence }\end{array}$ & $\begin{array}{c}13 \% \\
(5)\end{array}$ & $\begin{array}{l}25 \% \\
(10)\end{array}$ & $\begin{array}{l}25 \% \\
(10)\end{array}$ & $\begin{array}{l}25 \% \\
(10)\end{array}$ & $\begin{array}{c}13 \% \\
(5)\end{array}$ & 3.0 \\
\hline
\end{tabular}

Table 7. Percentage and Number of Instructors Reporting on their Expectations for Student Participation in Minds-on Instructional Methods

\section{Collaborative Instructional Methods}

Students were occasionally expected to engage in collaborative instructional activities (see Table 8). The most common collaborative activity was participating in student groups created to discuss course content, which instructors expected students to participate in an average of once or twice a month. The least common collaborative activity, perhaps because of the amount of time it takes to complete, was group work on projects or assignments that occur an average of once or twice during the course. Participating in students groups to complete group or individual assignments or to review each other's work occurred once or twice a month. 


\begin{tabular}{|c|c|c|c|c|c|c|}
\hline \multirow[b]{2}{*}{ Collaborative Activities \& Materials } & \multicolumn{5}{|c|}{$\begin{array}{c}\text { Percentage and Number of Instructors Expecting Students to } \\
\text { Engage in the Activity or With Course Materials }\end{array}$} & \multirow[b]{2}{*}{ Mean } \\
\hline & $\begin{array}{l}\text { Not at } \\
\text { All }\end{array}$ & $\begin{array}{l}\text { Once or Twice } \\
\text { During the } \\
\text { Course }\end{array}$ & $\begin{array}{l}\text { Once or } \\
\text { Twice a } \\
\text { Month }\end{array}$ & $\begin{array}{c}\text { Once or } \\
\text { Twice a } \\
\text { Week }\end{array}$ & $\begin{array}{l}\text { Three Times a } \\
\text { Week or More }\end{array}$ & \\
\hline \multirow{2}{*}{$\begin{array}{l}\text { Participated in student groups created to discuss } \\
\text { course content }\end{array}$} & $33 \%$ & $13 \%$ & $3 \%$ & $23 \%$ & $30 \%$ & \multirow[t]{2}{*}{3.1} \\
\hline & (13) & (5) & (1) & (9) & $(12)$ & \\
\hline \multirow{2}{*}{$\begin{array}{l}\text { Participated in student groups created to complete } \\
\text { assignments or activities }\end{array}$} & $38 \%$ & $18 \%$ & $18 \%$ & $10 \%$ & $18 \%$ & \multirow[t]{2}{*}{2.5} \\
\hline & (15) & (7) & (7) & (4) & (7) & \\
\hline \multirow{2}{*}{$\begin{array}{l}\text { Participated in student groups created to review each } \\
\text { otherÕs work }\end{array}$} & $58 \%$ & $13 \%$ & $13 \%$ & $10 \%$ & $8 \%$ & \multirow[t]{2}{*}{2.0} \\
\hline & (23) & (5) & (5) & (4) & (3) & \\
\hline $\begin{array}{l}\text { Worked as part of a team on group projects or } \\
\text { assignment }\end{array}$ & $\begin{array}{l}43 \% \\
(17)\end{array}$ & $\begin{array}{c}13 \% \\
(5)\end{array}$ & $\begin{array}{l}13 \% \\
(5)\end{array}$ & $\begin{array}{l}15 \% \\
(6)\end{array}$ & $\begin{array}{l}18 \% \\
(7)\end{array}$ & 1.5 \\
\hline \multicolumn{7}{|l|}{$\mathrm{N}=40$ instructors. } \\
\hline 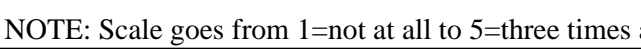 & a week & more in this $\mathrm{C}$ & & & & \\
\hline
\end{tabular}

Table 8. Percentage and Number of Instructors Reporting on their Expectations for Student Participation in Collaborative Instructional Methods

\section{Other Instructional Methods}

Nearly all of the remaining 17 instructional activities or materials were initially included in one of the four constructs (e.g., pen-and-paper, hands-on, etc.), but were dropped. They did not enhance the internal consistency of the scale because they were either (a) virtually non-existent in the courses or (b) so prevalent that they could have been used to support more than one instructional methodology (and did not cohere with just one). Instructors in at least half of the courses reported that at least once a week students were expected to:

- Read/listen to other students’ posts

- Respond to other students’ posts

- Use web-based readings

- Read/listen to instructor posts

- Use web-based images

- $\quad$ Respond to instructor posts

On the opposite end of the frequency continuum, at least half of the instructors reported that their students were never expected to:

- Use video files

- Use computer-based animations, games, or simulations (e.g., virtual dissection, SimEarth, flash interactives)

- Use presentation software

- Use physical materials

- Use interactive computer modules 
- Use graphing and data analysis tools

- Articulate their scientific ideas in a journal

- Participate in on-site fieldwork (e.g., water testing, species counting in a natural setting, astronomical observations of the night sky)

- Use spreadsheets

- Use audio files

- Interact with professional scientists (e.g., site visits)

- Participate in student groups created to prepare for tests

- Visit professional scientific environments (e.g., labs)

Instructional activities that varied in their use across courses include:

- Read professional scientific publications (e.g., journals, periodicals)

- Worked on problems based in contexts from their daily life

Combined, these other instructional activities and materials paint a picture of courses that made frequent use of online discussion boards (with participation in discussions accounting for more than $20 \%$ of the final course grade in $64 \%$ of the courses), but not many other online technologies. The use of other science education methods, such as pen-and-paper problems, collaborative activities, use of authentic contexts, and review of scientific literature, varied among the courses. Students were expected to participate frequently in minds-on activities such as articulating and reflecting on their scientific ideas and those of others, but rarely in hands-on activities. The use of pen and paper activities and collaboration varied among courses. 


\begin{tabular}{|c|c|c|c|c|c|c|}
\hline \multirow[b]{2}{*}{ Other activities and materials } & \multicolumn{5}{|c|}{$\begin{array}{c}\text { Percentage and Number of Instructors Expecting Students to } \\
\text { Engage in the Activity }\end{array}$} & \multirow[b]{2}{*}{ Mean } \\
\hline & $\begin{array}{l}\text { Not at } \\
\text { All }\end{array}$ & $\begin{array}{l}\text { Once or Twice } \\
\text { During the } \\
\text { Course }\end{array}$ & $\begin{array}{l}\text { Once or } \\
\text { Twice a } \\
\text { Month }\end{array}$ & $\begin{array}{c}\text { Once or } \\
\text { Twice a } \\
\text { Week }\end{array}$ & $\begin{array}{l}\text { Three Times a } \\
\text { Week or More }\end{array}$ & \\
\hline Read/listened to other studentsÕ posts & $\begin{array}{l}0 \% \\
(0)\end{array}$ & $\begin{array}{l}3 \% \\
(1)\end{array}$ & $\begin{array}{l}0 \% \\
(0)\end{array}$ & $\begin{array}{l}40 \% \\
(16)\end{array}$ & $\begin{array}{l}58 \% \\
(23)\end{array}$ & 4.5 \\
\hline Responded to other studentsÕ posts & $\begin{array}{l}0 \% \\
(0)\end{array}$ & $\begin{array}{l}3 \% \\
(1)\end{array}$ & $\begin{array}{l}5 \% \\
(2)\end{array}$ & $\begin{array}{l}50 \% \\
(20)\end{array}$ & $\begin{array}{l}43 \% \\
(17)\end{array}$ & 4.3 \\
\hline Web-based readings & $\begin{array}{l}0 \% \\
(0)\end{array}$ & $\begin{array}{l}3 \% \\
(1)\end{array}$ & $\begin{array}{l}8 \% \\
(3)\end{array}$ & $\begin{array}{l}33 \% \\
(13)\end{array}$ & $\begin{array}{l}58 \% \\
(23)\end{array}$ & 4.5 \\
\hline Read/listened to instructor posts & $\begin{array}{l}0 \% \\
(0)\end{array}$ & $\begin{array}{l}3 \% \\
(1)\end{array}$ & $\begin{array}{l}3 \% \\
(1)\end{array}$ & $\begin{array}{l}63 \% \\
(25)\end{array}$ & $\begin{array}{l}33 \% \\
(13)\end{array}$ & 4.3 \\
\hline Images & $\begin{array}{l}5 \% \\
(2)\end{array}$ & $\begin{array}{l}8 \% \\
(3)\end{array}$ & $\begin{array}{l}5 \% \\
(2)\end{array}$ & $\begin{array}{l}38 \% \\
(15)\end{array}$ & $\begin{array}{l}45 \% \\
(18)\end{array}$ & 4.1 \\
\hline Responded to instructor posts & $\begin{array}{l}3 \% \\
(1)\end{array}$ & $\begin{array}{l}5 \% \\
(2)\end{array}$ & $\begin{array}{l}13 \% \\
(5)\end{array}$ & $\begin{array}{l}63 \% \\
(25)\end{array}$ & $\begin{array}{l}18 \% \\
(7)\end{array}$ & 3.9 \\
\hline $\begin{array}{l}\text { Read professional scientific publications (e.g., journals, } \\
\text { periodicals) }\end{array}$ & $\begin{array}{c}15 \% \\
(6)\end{array}$ & $\begin{array}{c}18 \% \\
(7)\end{array}$ & $\begin{array}{c}23 \% \\
(9)\end{array}$ & $\begin{array}{l}35 \% \\
(14)\end{array}$ & $\begin{array}{c}10 \% \\
(4)\end{array}$ & 3.1 \\
\hline Worked on problems based in contexts from their daily life & $\begin{array}{c}20 \% \\
(8)\end{array}$ & $\begin{array}{r}28 \% \\
(11)\end{array}$ & $\begin{array}{l}33 \% \\
(13)\end{array}$ & $\begin{array}{l}13 \% \\
(5)\end{array}$ & $\begin{array}{l}8 \% \\
(3)\end{array}$ & 2.6 \\
\hline Video files & $\begin{array}{l}50 \% \\
(20)\end{array}$ & $\begin{array}{l}20 \% \\
(8)\end{array}$ & $\begin{array}{l}10 \% \\
(4)\end{array}$ & $\begin{array}{l}10 \% \\
(4)\end{array}$ & $\begin{array}{l}10 \% \\
(4)\end{array}$ & 2.1 \\
\hline $\begin{array}{l}\text { Used computer-based animations, games, or simulations } \\
\text { (e.g., virtual dissection, SimEarth, flash interactives) }\end{array}$ & $\begin{array}{l}53 \% \\
(21)\end{array}$ & $\begin{array}{c}23 \% \\
(9)\end{array}$ & $\begin{array}{l}5 \% \\
(2)\end{array}$ & $\begin{array}{c}13 \% \\
(5)\end{array}$ & $\begin{array}{l}8 \% \\
(3)\end{array}$ & 2.0 \\
\hline Presentation software & $\begin{array}{l}50 \% \\
(20)\end{array}$ & $\begin{array}{l}35 \% \\
(14)\end{array}$ & $\begin{array}{c}13 \% \\
(5)\end{array}$ & $\begin{array}{l}3 \% \\
(1)\end{array}$ & $\begin{array}{l}0 \% \\
(0)\end{array}$ & 1.7 \\
\hline Physical materials & $\begin{array}{l}63 \% \\
(25)\end{array}$ & $\begin{array}{c}23 \% \\
(9)\end{array}$ & $\begin{array}{l}3 \% \\
(1)\end{array}$ & $\begin{array}{c}13 \% \\
(5)\end{array}$ & $\begin{array}{l}0 \% \\
(0)\end{array}$ & 1.7 \\
\hline Interactive computer modules & $\begin{array}{l}68 \% \\
\text { (27) }\end{array}$ & $\begin{array}{c}15 \% \\
(6)\end{array}$ & $\begin{array}{c}13 \% \\
(5)\end{array}$ & $\begin{array}{l}3 \% \\
(1)\end{array}$ & $\begin{array}{l}3 \% \\
(1)\end{array}$ & 1.6 \\
\hline Graphing and data analysis tools & $\begin{array}{l}70 \% \\
(28)\end{array}$ & $\begin{array}{c}20 \% \\
(8)\end{array}$ & $\begin{array}{l}8 \% \\
(3)\end{array}$ & $\begin{array}{l}3 \% \\
(1)\end{array}$ & $\begin{array}{l}0 \% \\
(0)\end{array}$ & 1.4 \\
\hline Articulated their scientific ideas in a journal. & $\begin{array}{l}85 \% \\
(34)\end{array}$ & $\begin{array}{l}5 \% \\
(2)\end{array}$ & $\begin{array}{l}3 \% \\
(1)\end{array}$ & $\begin{array}{l}3 \% \\
(1)\end{array}$ & $\begin{array}{l}5 \% \\
(2)\end{array}$ & 1.4 \\
\hline $\begin{array}{l}\text { Participated in on-site fieldwork (e.g., water testing, species } \\
\text { counting in a natural setting, astronomical observations of the } \\
\text { night sky) }\end{array}$ & $\begin{array}{l}83 \% \\
\text { (33) }\end{array}$ & $\begin{array}{c}13 \% \\
(5)\end{array}$ & $\begin{array}{c}13 \% \\
(2)\end{array}$ & $\begin{array}{l}0 \% \\
(0)\end{array}$ & $\begin{array}{l}0 \% \\
(0)\end{array}$ & 1.2 \\
\hline Spreadsheets & $\begin{array}{l}80 \% \\
(32)\end{array}$ & $\begin{array}{c}18 \% \\
(7)\end{array}$ & $\begin{array}{l}3 \% \\
(1)\end{array}$ & $\begin{array}{l}0 \% \\
(0)\end{array}$ & $\begin{array}{l}0 \% \\
(0)\end{array}$ & 1.2 \\
\hline Audio files & $\begin{array}{l}88 \% \\
(35)\end{array}$ & $\begin{array}{l}5 \% \\
(2)\end{array}$ & $\begin{array}{l}5 \% \\
\text { (2) }\end{array}$ & $\begin{array}{l}3 \% \\
(1)\end{array}$ & $\begin{array}{l}0 \% \\
(0)\end{array}$ & 1.2 \\
\hline Interacted with professional scientists (site visits) & $\begin{array}{l}88 \% \\
(35)\end{array}$ & $\begin{array}{c}10 \% \\
(4)\end{array}$ & $\begin{array}{l}3 \% \\
\text { (1) }\end{array}$ & $\begin{array}{l}0 \% \\
(0)\end{array}$ & $\begin{array}{l}0 \% \\
(0)\end{array}$ & 1.2 \\
\hline Participated in student groups created to prepare for tests & $\begin{array}{l}93 \% \\
(37)\end{array}$ & $\begin{array}{l}3 \% \\
(1)\end{array}$ & $\begin{array}{l}5 \% \\
(2)\end{array}$ & $\begin{array}{l}0 \% \\
(0)\end{array}$ & $\begin{array}{l}0 \% \\
(0)\end{array}$ & 1.1 \\
\hline Visited professional scientific environments (e.g., labs) & $\begin{array}{c}100 \% \\
(40)\end{array}$ & $\begin{array}{l}0 \% \\
(0)\end{array}$ & $\begin{array}{l}0 \% \\
(0)\end{array}$ & $\begin{array}{l}0 \% \\
(0)\end{array}$ & $\begin{array}{l}0 \% \\
(0)\end{array}$ & 1.0 \\
\hline
\end{tabular}

Table 9. Percentage and Number of Instructors Reporting on their Expectations for Student Engagement with Other Instructional Activities and Materials 


\section{B. What is the Nature of Communication Between Students and Instructors in Online Science Courses for Teachers?}

None of the courses in this study met face-to-face. If they aren't communicating in person, what technologies are the students using to communicate with instructors and each other? More important than the technologies used is the content of this communication and the climate it creates in the course. Students and instructors were asked about their perceptions of this climate. Specifically of interest was: (a) who initiated topics during online discussions; (b) who contributed to the online discussions; and (c) the frequency and perceived helpfulness of instructor and student feedback.

To understand the media used for communication in these courses, instructors were asked how often they expected students to communicate with them and each other via eight communication media. Instructors expected students to use one of three media to communicate in these courses: (1) e-mail, (2) discussion boards, and (3) synchronous chat. No instructors expected students to communicate with them or each other via paper mail, telephone, video conferencing, or white board. Discussion boards were the sites of the most frequent instructor-student and student-student communication, with $60 \%$ of instructors expecting students to use discussion boards to contact them at least once a week and $58 \%$ of the instructors expecting students to contact each other via discussion boards three times a week or more.

Instructors and students were asked who chose new discussion topics—students or instructors (see Table 10). In most courses, instructors and students reported instructors chose most if not all of the topics in the online discussions (53\% of instructors, $63 \%$ of students). Most instructors and students reported that nearly all students contributed to these discussions, with some students contributing more than others.

In addition to discussing science content, another potential role of communication is providing feedback. Students were asked about the frequency with which they received feedback from instructors and other students on their science learning in the course. Almost seven out of ten students $(n=203)$ reported receiving feedback from instructors and students at least once a week, but they reported the feedback from instructors as significantly more helpful than feedback from other students $(t=5.40,288$ d.f., $\mathrm{p}<0.001)$.

Overall, communication is a large part of these online courses. Discussion boards are used as the primary communication tool in these courses, with expectations of use 3 times or more per week typically, and nearly all students reported contributing to discussion. The instructor, however, is still reported to be choosing most of the topics for discussion. Students reported receiving frequent feedback from the instructor, and finding it helpful. 


\section{Aspects of Online Discussion}

$\begin{array}{cc}\begin{array}{c}\text { Percentage of } \\ \text { Students }\end{array} & \begin{array}{c}\text { Percentage of } \\ \text { Instructors } \\ (n=289)\end{array} \\ (n=40)\end{array}$

Who chose new topics within the online discussions

Students chose nearly all of the new topics in the online discussions.

\begin{tabular}{cc}
$8 \%$ & $3 \%$ \\
\hline $14 \%$ & $25 \%$ \\
\hline $15 \%$ & $20 \%$ \\
\hline $24 \%$ & $20 \%$ \\
\hline $39 \%$ & $33 \%$ \\
\hline $0 \%$ & $0 \%$
\end{tabular}

Students chose most of the new topics in the online discussions. Instructors chose a few of the new topics in the online discussions.

Students and instructors were equally likely to have chosen new topics in the online discussions.

Instructors chose most new topics in the online discussions. Students chose a few of the new topics in the online discussions.

Instructors chose nearly all new topics in the online discussions.

No response

Who contributed to online discussions

A small group of students were the main contributors to discussions in this course. Most students did not contribute to discussions.

Over half of the students contributed to discussions, but some students contributed more than others.

Over half of the students contributed equally to discussions.

\begin{tabular}{ll}
$3 \%$ & $3 \%$ \\
$63 \%$ & $68 \%$ \\
\hline $12 \%$ & $13 \%$
\end{tabular}

Nearly all students contributed to discussions, but some students contributed more than others.

$0 \%$

$0 \%$

Table 10. Percentage of Students and Instructors Who Initiated and Contributed to Online Discussions

\section{What is the Extent of Support Perceived by Students from their Instructors, Other Students, and the Course Environment?}

Students were asked their perceptions about the support they received from instructors, students, and course environment. The internal consistency of these support scales ranged from alphas of 0.77 (course supports) to 0.88 (instructor supports). Overall, there was a high level of perceived support from all sources.

\section{Perceived Instructor Support}

Student perceptions of instructor support are presented in Table 11. Students perceived a high level of 
support from their instructors, with 90 percent of the students agreeing that 'The instructor was accessible to me.' Three-quarters of the students agreed that 'Interactions with the instructor helped me understand the course material better.'

\begin{tabular}{|c|c|c|c|c|c|c|}
\hline \multirow[b]{2}{*}{ Dimension of Instructor Support } & \multicolumn{5}{|c|}{ Percentage and Number of Students: } & \multirow{2}{*}{$\begin{array}{l}\text { Mean } \\
\text { (S.D.) }\end{array}$} \\
\hline & $\begin{array}{l}\text { Strongly } \\
\text { Disagree }\end{array}$ & Disagree & Neutral & Agree & $\begin{array}{c}\begin{array}{c}\text { Strongly } \\
\text { agree }\end{array} \\
\end{array}$ & \\
\hline The instructor was accessible to me. & $\begin{array}{l}1 \% \\
(3)\end{array}$ & $\begin{array}{l}1 \% \\
(3)\end{array}$ & $\begin{array}{l}5 \% \\
(14)\end{array}$ & $\begin{array}{l}47 \% \\
(140)\end{array}$ & $\begin{array}{l}46 \% \\
(136)\end{array}$ & $\begin{array}{c}4.4 \\
(0.71)\end{array}$ \\
\hline $\begin{array}{l}\text { I felt supported by the instructor(s) as I developed my } \\
\text { understanding of the course material. }\end{array}$ & $\begin{array}{l}2 \% \\
(6)\end{array}$ & $\begin{array}{r}5 \% \\
(15)\end{array}$ & $\begin{array}{l}10 \% \\
(29)\end{array}$ & $\begin{array}{l}50 \% \\
(148)\end{array}$ & $\begin{array}{l}33 \% \\
(98)\end{array}$ & $\begin{array}{c}4.1 \\
(0.90)\end{array}$ \\
\hline $\begin{array}{l}\text { I was encouraged to provide feedback to the instructors about my } \\
\text { questions and concerns about the course. }\end{array}$ & $\begin{array}{l}1 \% \\
(3)\end{array}$ & $\begin{array}{r}4 \% \\
(13)\end{array}$ & $\begin{array}{l}14 \% \\
(40)\end{array}$ & $\begin{array}{l}49 \% \\
(146)\end{array}$ & $\begin{array}{l}32 \% \\
(94)\end{array}$ & $\begin{array}{c}4.1 \\
(0.85)\end{array}$ \\
\hline $\begin{array}{l}\text { I felt my contributions to the online discussions were valued by the } \\
\text { instructor. }\end{array}$ & $\begin{array}{l}1 \% \\
(4)\end{array}$ & $\begin{array}{l}3 \% \\
(9)\end{array}$ & $\begin{array}{l}16 \% \\
(48)\end{array}$ & $\begin{array}{r}55 \% \\
(162)\end{array}$ & $\begin{array}{l}25 \% \\
(73)\end{array}$ & $\begin{array}{c}4.0 \\
(0.81)\end{array}$ \\
\hline $\begin{array}{l}\text { Interactions with the instructor helped me understand the course } \\
\text { material better. }\end{array}$ & $\begin{array}{l}2 \% \\
(7)\end{array}$ & $\begin{array}{r}7 \% \\
(21)\end{array}$ & $\begin{array}{l}16 \% \\
(47)\end{array}$ & $\begin{array}{l}47 \% \\
(140)\end{array}$ & $\begin{array}{l}27 \% \\
(81)\end{array}$ & $\begin{array}{c}3.9 \\
(0.96)\end{array}$ \\
\hline
\end{tabular}

Table 11. Percentage and Number of Students Reporting their Level of Agreement with Specific Statements about Perceived Support from the Instructor

\section{Perceived Student Support}

Students' perceptions of dimensions of student support are reported in Table 12. Students most strongly agreed that 'the class environment encouraged me to participate in discussions,' with $79 \%$ of the students agreeing or strongly agreeing with that statement. Slightly smaller percentages of students agreed that interactions with other students helped them better understand the course content, that they felt their contributions were valued by other students, or that they felt supported in their learning by other students.

\begin{tabular}{|c|c|c|c|c|c|c|}
\hline \multirow[b]{2}{*}{ Dimension of Student Support } & \multicolumn{5}{|c|}{ Percentage and Number of Students: } & \multirow{2}{*}{$\begin{array}{l}\text { Mean } \\
\text { (S.D.) }\end{array}$} \\
\hline & $\begin{array}{l}\text { Strongly } \\
\text { Disagree }\end{array}$ & Disagree & Neutral & Agree & $\begin{array}{c}\begin{array}{c}\text { Strongly } \\
\text { agree }\end{array} \\
\end{array}$ & \\
\hline $\begin{array}{l}\text { The class atmosphere encouraged me to make contributions to the } \\
\text { online discussions. }\end{array}$ & $\begin{array}{l}0 \% \\
(0)\end{array}$ & $\begin{array}{r}5 \% \\
(16)\end{array}$ & $\begin{array}{l}15 \% \\
(45)\end{array}$ & $\begin{array}{l}54 \% \\
(160)\end{array}$ & $\begin{array}{l}25 \% \\
(75)\end{array}$ & $\begin{array}{c}4.0 \\
(0.79)\end{array}$ \\
\hline $\begin{array}{l}\text { Interactions with the other students helped me understand the course } \\
\text { material better. }\end{array}$ & $\begin{array}{l}1 \% \\
(4)\end{array}$ & $\begin{array}{r}6 \% \\
(18)\end{array}$ & $\begin{array}{l}18 \% \\
(54)\end{array}$ & $\begin{array}{l}49 \% \\
(145)\end{array}$ & $\begin{array}{l}25 \% \\
(75)\end{array}$ & $\begin{array}{c}3.9 \\
(0.89)\end{array}$ \\
\hline $\begin{array}{l}\text { I felt my contributions to the online discussions were valued by other } \\
\text { students. }\end{array}$ & $\begin{array}{l}0 \% \\
(0)\end{array}$ & $\begin{array}{r}4 \% \\
(13)\end{array}$ & $\begin{array}{l}21 \% \\
(63)\end{array}$ & $\begin{array}{c}56 \% \\
(165)\end{array}$ & $\begin{array}{l}19 \% \\
(55)\end{array}$ & $\begin{array}{c}3.9 \\
(0.75)\end{array}$ \\
\hline $\begin{array}{l}\text { I felt supported by other students as I developed my understanding of } \\
\text { the course content. }\end{array}$ & $\begin{array}{l}0 \% \\
(1)\end{array}$ & $\begin{array}{r}6 \% \\
(17)\end{array}$ & $\begin{array}{l}24 \% \\
(70)\end{array}$ & $\begin{array}{c}50 \% \\
(147)\end{array}$ & $\begin{array}{l}21 \% \\
(61)\end{array}$ & $\begin{array}{c}3.8 \\
(0.83)\end{array}$ \\
\hline
\end{tabular}

$\mathrm{N}=296$ students who completed pre- and post-questionnaires.

NOTE: Scale goes from $1=$ strongly disagree to $5=$ strongly agree.

Table 12. Percentage and Number of Students Reporting their Level of Agreement with Specific Statements about Perceived Support from Students 


\section{Perceived Course Support}

Student perceptions of support from the course environment displayed the greatest diversity (see Table 13). Students reported the highest level of agreement that they 'usually understood the content being taught in the course.' Interestingly, mean levels of agreement were significantly lower when asked about the course being designed for multiple learning styles (mean=3.4) despite higher levels of agreement that their own learning style was well suited for their course (mean=4.0). Students generally agreed that the course materials made connections between concepts clear.

\begin{tabular}{|c|c|c|c|c|c|c|}
\hline \multirow[b]{2}{*}{ Dimension of Course Support } & \multicolumn{5}{|c|}{ Percentage and Number of Students: } & \multirow{2}{*}{$\begin{array}{l}\text { Mean } \\
\text { (S.D.) }\end{array}$} \\
\hline & $\begin{array}{l}\text { Strongly } \\
\text { Disagree }\end{array}$ & Disagree & Neutral & Agree & $\begin{array}{c}\begin{array}{c}\text { Strongly } \\
\text { agree }\end{array} \\
\end{array}$ & \\
\hline I usually understood the content being taught in the course. & $\begin{array}{l}1 \% \\
(2)\end{array}$ & $\begin{array}{l}3 \% \\
(8)\end{array}$ & $\begin{array}{r}4 \% \\
(12)\end{array}$ & $\begin{array}{r}57 \% \\
(169)\end{array}$ & $\begin{array}{r}35 \% \\
(105)\end{array}$ & $\begin{array}{c}4.2 \\
(0.71)\end{array}$ \\
\hline I felt my learning style was well suited for this course. & $\begin{array}{l}1 \% \\
(2)\end{array}$ & $\begin{array}{r}5 \% \\
(14)\end{array}$ & $\begin{array}{l}15 \% \\
(43)\end{array}$ & $\begin{array}{r}54 \% \\
(159)\end{array}$ & $\begin{array}{l}26 \% \\
(78)\end{array}$ & $\begin{array}{c}4.0 \\
(0.81)\end{array}$ \\
\hline $\begin{array}{l}\text { Course materials were organized so it was clear how different } \\
\text { concepts covered in this course fit together. }\end{array}$ & $\begin{array}{l}1 \% \\
(2)\end{array}$ & $\begin{array}{r}4 \% \\
(12)\end{array}$ & $\begin{array}{l}12 \% \\
(35)\end{array}$ & $\begin{array}{r}62 \% \\
(184)\end{array}$ & $\begin{array}{l}21 \% \\
(63)\end{array}$ & $\begin{array}{c}4.0 \\
(0.75)\end{array}$ \\
\hline $\begin{array}{l}\text { Course materials were organized so that each new concept built upon } \\
\text { previous learning. }\end{array}$ & $\begin{array}{l}1 \% \\
(2)\end{array}$ & $\begin{array}{r}5 \% \\
(16)\end{array}$ & $\begin{array}{l}14 \% \\
(41)\end{array}$ & $\begin{array}{c}60 \% \\
(178)\end{array}$ & $\begin{array}{l}20 \% \\
(59)\end{array}$ & $\begin{array}{c}3.9 \\
(0.78)\end{array}$ \\
\hline The course seemed to be designed to address multiple learning styles. & $\begin{array}{l}2 \% \\
\text { (6) }\end{array}$ & $\begin{array}{l}20 \% \\
(60)\end{array}$ & $\begin{array}{l}29 \% \\
(86)\end{array}$ & $\begin{array}{c}36 \% \\
(106)\end{array}$ & $\begin{array}{l}13 \% \\
\text { (38) }\end{array}$ & $\begin{array}{c}3.4 \\
(1.01)\end{array}$ \\
\hline $\begin{array}{l}\text { N=296 students who completed pre- and post-questionnaires. } \\
\text { NOTE: Scale goes from 1=strongly disagree to } 5=\text { strongly agree. }\end{array}$ & & & & & & \\
\hline
\end{tabular}

Table 13. Percentage and Number of Students Reporting their Level of Agreement with Specific Statements about Perceived Support from the Course Environment

Overall, students felt very high levels of supports from their instructors, other students, and for the most part, course design. The one slight exception to this is on the question of whether or not this course meets multiple learning styles, where students were less likely to agree. Interestingly, however, they did believe that the course was a good match for their own learning style. Students report participating frequently in mind-on activities, such as articulating and reflecting upon scientific ideas.

\section{Limitations of the Study}

When interpreting these findings, there are two limitations of this study that should be borne in mind. First, the students who completed all components of the study, and thus were counted in our sample, were more likely to earn higher final course grades than students not participating in the study. The sample also does not include, naturally, students who chose not to take an online science course or students who dropped out during the course. Thus, these findings reflect those who "made it" and may be biased towards those who have proficiency in either the content or in online modes of learning. These findings cannot be generalized to all learners seeking science professional development. In particular, students who did not perceive high levels of support from the instructor, other students, or the course design may not have completed the course, or may not have participated in the study. Those students who were at risk may have also reported a different dynamic in communication within the course, and we may be seeing a "best-case" scenario in these findings. Student and instructor reports of instructional methods were strongly correlated, however, so there is no reason to believe those findings would be biased by the selectivity of the student sample. 
The second source of selectivity - the emphasis on courses designed for high school teachers — could influence the instructional methods as well as communication and perceived supports reported here. High school teachers are generally better prepared in science than elementary school teachers, and indeed, most teachers in our sample have a bachelor's degree in science. The lack of hands-on activities found in these courses may reflect this emphasis towards high-school science that is typically thought of as having more direct instruction and pen-and-paper problem sets than elementary science. It could be argued, however, that elementary teachers are more aware and educated about students' individual and social needs as learners and one might expect that instructional methods associated with social learning and inquirybased science are found to be less prevalent with high school teachers than elementary teachers. If so, then the prevalence of social instructional methods, such as discussion and collaboration, which occurred frequently in these courses, may be underestimated in this study.

\section{IMPLICATIONS}

Many of the findings from LSO are encouraging, in that they show innovative uses of new technologies that appear to foster learning in ways advocated for by relevant research and national standards for professional development for science teachers. There are also many areas in which online developers have room for growth in imaginative design of courses. Students report feeling a high sense of support and communicate frequently with their instructor and other students, debunking myths of isolation and alienation in online education.

A primary instructional method in virtually all of the courses studied is the use of asynchronous discussion boards. Instructors reported frequent student participation in minds-on activities, such as articulation and reflection of their scientific ideas and the ideas of others, which one might expect when the discussion is such a central focus of the course. Further research is needed to assess the cognitive depth of these discussions and the relevance of the discussion to students' scientific inquiry and their construction of knowledge.

Interestingly, the use of other online technologies such as simulations, visualizations, and interactives are relatively absent from these courses. The promise of re-usable learning objects does not seem to have become a reality in this setting, and also notably missing are frequent hands-on activities. In many faceto-face science teacher professional development courses, hands-on investigation is rampant. It appears to have been replaced by more minds-on work and discussion in these online courses. While the potential of online discussions for knowledge construction is certainly a fascinating area for future research and development, there may be even more value added when visualization tools and hands-on activity are integrated with discussions for an even richer learning environment.

The communication in online science courses for teachers is dominated by the use of asynchronous discussion boards. While instructors chose most of the topics for discussion, suggesting that a structure was designed by the instructor for learning as opposed to a purely open-ended conversation, students also reported that most students participated. This begins to portray a vision of a community of learners having possibly found their legitimate roles of participation [45]. The instructor still plays an important role for these students - they see the feedback from their instructor as more useful than feedback from their peers, and they receive their instructors' feedback frequently. The dynamics of communication found in these courses is encouraging and suggests that these environments would be ripe for research on the extent of knowledge construction measurable in these highly social learning communities.

The support perceived by students from these online courses was high in nearly all aspects. Students 
certainly reported feeling support from their instructors with high levels of agreement that their instructor was accessible and made them feel them feel like a valued contributor to the learning experience. Students rated their support from their fellow students slightly lower than that from their instructor, but still felt valued and supported by their peers. They reported that interactions with their instructor helped them understand the material better, and so did interactions with other students, but again to a slightly lesser extent. The organization of the course materials and chosen level of instruction were also perceived to be supportive to students, though students were less likely to agree that the materials would suit many different learning styles. Together these findings suggest that online science courses for teachers have reached a level of maturity where designers and instructors are crafting supportive course climates.

\section{CONCLUSION}

Online professional development for teachers is a growing phenomenon that presents unique and rich opportunities for research and the LSO study of 40 online courses for science teachers is just a beginning. Students participating in these courses report feeling supported by their instructors, peers, and course design. Asynchronous discussion boards are used as a primary instructional tool in nearly all of the courses. The textual, archivable, and asynchronous properties of online discussion boards provide rich potential for the social construction of knowledge when students take time to articulate their thoughts and questions, gain perspective from the ideas and questions of others, and reflect upon their previous ideas. Students in LSO courses report participating frequently in mind-on activities such as articulating and reflecting upon scientific ideas. This type of online discussions may promote metacognition and other ways of learning different from what happens in conventional, face-to-face settings. As their use becomes more and more prevalent in the educational community, online discussions and online courses in general merit further research to both examine their effectiveness and also to utilize the new lens they may offer into the learning process, in particular the social construction of knowledge.

\section{ACKNOWLEDGMENTS}

This study was supported by funding from the National Science Foundation, Gender in Science and Engineering program (Grant HRD-0332602). An early version of these results was presented at the 2006 American Educational Research Association's Annual Meeting [46]. A forthcoming TERC report will present a more complete version of this study with detailed methodology [47]. Polly Hubbard, Stacey Leibowitz, Tsana Dimanin, and Senofer Stead all contributed substantially to the collection and tabulation of the data reported here. This study would not have been completed without their efforts. Laura Uhl contributed valuable editorial feedback and improved the writing immensely. Last, but certainly not least, this study has benefited tremendously from a thorough review by study participants and the LSO advisory board members, including Gwyneth Boodoo, June Foster, Sarah Haavind, Jane Butler Kahle, Linda Polin, and Karen Sheingold. Any remaining errors or mis-statements, of course, are the responsibility of the authors.

\section{ABOUT THE AUTHORS}

Jodi Asbell-Clarke (PI) is a senior science educator at TERC. She is principal investigator and project director of the Learning Science Online study and led various science education curriculum and research projects at TERC. She is currently principal investigator of the Investigating Astronomy high school astronomy curriculum project and co-PI of The Inquiry Project, a study of children's learning progression in the nature of matter. She has taught graduate online courses in science education at Lesley University (Cambridge, MA) and currently teaches science online to undergraduate non-science majors at Saint Mary's University (Halifax, NS). She has a bachelor's degree in Applied Math from Rochester Institute 
of Technology, an M.A. in Applied Mathematical Sciences from Rice University, and an M.S. in Astrophysics from University of New Mexico. She has worked for IBM as a systems analyst on the onboard space shuttle software and taught high school astronomy and physics at University High School in Urbana, IL.

Elizabeth Rowe, Ph.D. (co-PI), a senior researcher at TERC, is co-principal investigator of the Learning Science Online study. Dr. Rowe has led the formative and summative evaluations of several teacher professional development programs including TERC's Foundational Tools for Data Literacy project, Massachusetts Technology Leadership Consortium; the PALMS-Alliance Mathematics Learning Community project; the Harvard University Programs in Professional Education's Media and American Democracy program; and TERC's Using Data Project. Prior to joining TERC, Dr. Rowe was a research analyst at the American Institutes for Research. Dr. Rowe has extensive quantitative research experience and studies ways technology can support mathematics and science learning. She holds a bachelor's degree in mathematics from the University of the Pacific and a Ph.D. in human development and family studies from Cornell University.

\section{REFERENCES}

1. National Center for Education Statistics. Digest of Education Statistics, 2005. U.S. Department of Education, (NCES 2006-005), 2005. http://nces.ed.gov/programs/digest/d05/.

2. Allen, I. E. and J. Seaman. Entering the Mainstream: The Quality and Extent of Online Education in the United States, 2003 and 2004. Needham, MA: Sloan Consortium, 2004. http://www.sloanc.org/publications/survey/pdf/entering_mainstream.pdf.

3. Allen, I. E. and J. Seaman. Making the Grade: Online Education in the United States, 2006. Needham, MA: Sloan Consortium, 2006. http://www.sloan-c.org/publications/survey/pdf /making_the_grade.pdf.

4. Scarafiotti, C. and M. Cleveland-Innis. The times they are a-changing. Journal of Asynchronous Learning Networks 10(2): 2006.

5. Obbink, K. and G. Wheeler. Teaching and learning via the network: National Teacher Enhancement Network. Network Coalition for Networked Information, Project Number 33, 1993. http://www.cni.org/projects/netteach/1993/prop33.html.

6. Scanlon, E., C. Colwell, M. Cooper and T. Di Paolo. Remote experiments, re-versioning and rethinking science learning. Computers and Education 43(1-2): 153-163, 2004.

7. Seiber, J. E. Misconceptions and realities about teaching online. Science and Engineering Ethics 11: 329-340, 2005.

8. Paloff, R. and K. Platt. Building Learning Communities in Cyberspace: Effective Strategies for the Online Classroom: 21-32, 73-86, 167. San Francisco, Jossey-Bass, 1999.

9. Allen, I. E. and J. Seaman. Growing by Degrees: Online Education in the United States, 2005. Needham, MA: Sloan Consortium, 2005. http://www.sloan-c.org/publications/survey/pdf /growing_by_degrees.pdf.

10. Garrison, D., T. Anderson and W. Archer. Critical inquiry in a text based environment; Computer conferencing in higher education. The Internet and Higher Education 2(2-3): 1-19, 2000.

11. Dede, C., P. Whitehouse and T. Brown-L'Bahy. Designing and studying learning experiences that use multiple interactive media to bridge distance and time. Current Perspectives on Applied Information Technologies 1: Distance Education, 2002.

12. Vygotsky, L. S. Mind and Society: The Development of Higher Mental Processes. Cambridge, MA: Harvard University Press, 1978.

13. National Research Council. National Science Education Standards. Washington, D.C., National Academy Press, 1996. 
14. Loucks-Horsley, S. The role of teaching and learning in systemic reform: A focus on professional development. Science Educator 7(1): 1-6, 1998.

15. Kuhn, D. Theory of mind, metacognition, and reasoning: a life-span perspective. In P. Mitchell and K. J. Riggs (Eds.), Children's Reasoning and the Mind. Hove, UK: Psychology Press, 2000.

16. Blanchette, J. Textual interactions handbook: Computer-mediated conferencing. In D. Collett (Ed.), Learning Technologies in Distance Education, HB65-HB96. Edmonton, AB: University of Alberta, 1999.

17. Singer, S.R., M. L. Hilton and H. A. Schweingruber. (Eds.) America's Lab Report: Investigations in High School Science. Committee on High School Science Laboratories: Role and Vision, National Research Council, 2005.

18. Woodfield, B. F., M. B. Andrus, T. Andersen, J. Miller, B. Simons, R. Stanger, G. L. Waddoups, M. S. Moore, R. Swan, R. Allen and G. Bodily. The Virtual ChemLab Project: A realistic and sophisticated simulation of organic synthesis and organic qualitative analysis. J. Chem. Ed, 82: 17281735, 2005.

19. Harlen, W. and C. Altobello. An Investigation of "Try Science" Studied On-Line and Face-to-Face. Cambridge, MA: TERC, 2003.

20. Sproull, L. and S. Keisler. Reducing social context cues: Electronic mail in organizational communication. Management Science 32: 1492-1513, 1986.

21. Walther, J. Interpersonal effects in computer mediated interaction. Communication Research 21(4): 460-487, 1994.

22. Garrison, D. R. Cognitive presence for effective asynchronous online learning: the role of reflective inquiry, self-direction and metacognition. In J. Bourne and J. C. Moore (Eds.), Elements of Quality Online Education: Practice and Direction, 47-58. Needham, MA: Sloan-C, 2003.

23. Garrison, D. R., T. Anderson and W. Archer. Critical inquiry in a text-based environment: Computer conferencing in higher education. The Internet and Higher Education 11(2): 1-14, 2000. http://communitiesofinquiry.com/documents/CTinTextEnvFinal.pdf.

24. Short, J., E. Williams and B. Christie. The Social Psychology of Telecommunications. Toronto: Wiley, 1976.

25. Picciano, A. G. Beyond student perceptions: Issues of interaction, presence and performance in an online course. Journal of Asynchronous Learning Networks 6(1): 2002.

26. Brown, R. The process of community building in distance learning classes. Journal of Asynchronous Learning Networks 5(2): 18-35, 2001.

27. Anderson, T., L. Rourke, D. R. Garrison and W. Archer. Assessing teaching presence in a computer conferencing context. Journal of Asynchronous Learning Networks 5(2): 1-17, 2001.

28. Madden, M. Internet Penetration and Impact. Pew Internet \& American Life Project, Pew/Internet, Washington DC, 2006.

29. Wallace, R. Online learning in higher education: A review of research on interactions among teachers and students. Education, Communication \& Information 3(2): 241-280, 2003.

30. Collison, G., B. Elbaum, S. Haavind and R. Tinker. Facilitating On-line Learning: Effective Strategies for Moderators. Madison, WI: Atwood Publishing, 2000.

31. Bonk, C., R. A. Wisher and J. Y. Lee. Moderating learner-centered e-learning: Problems and solutions, benefits and implications. In T. S. Roberts (Ed.), Online Collaborative Learning: Theory and Practice, 54-85. Hershey, PA: Information Science Publishing, 2004.

32. Arbaugh, J. B. How instructor immediacy behaviors affect student satisfaction and learning in webbased courses. Business Communication Quarterly 64(4): 42-45, 2001.

33. Arbaugh, J. B. Managing the on-line classroom: A study of technological and behavioral characteristics of web-based MBA courses. Journal of High Technology Management Research 13: 203-223, 2002.

34. Berge, Z. L. Barriers to online teaching in post-secondary institutions. Can policy changes fix it? Online Journal of Distance Learning Administration 1(2): 1998. 
35. Garrison, D. Online collaboration principles. Journal of Asynchronous Learning Networks 10(1): 2006.

36. Gunawardena, C. Social presence theory and implications for interaction and collaborative learning in computer conferences. International Journal of Educational Telecommunications 1(2/3): 147-166, 1995.

37. Rourke, L., T. Anderson, D. R. Garrison and W. Archer. Assessing social presence in asynchronous text-based computer conferencing. Journal of Distance Education 14(2): 2001.

38. Swan, K. Building communities in online courses: the importance of interaction. Education, Communication and Information 2(1): 23-49, 2002.

39. Gunawardena, C. and F. Zittle. Social presence as a predictor of satisfaction within a computer mediated conferencing environment. American Journal of Distance Education 11(3): 8-26, 1997.

40. Richardson, J. C. and K. Swan. Examining social presence in online courses in relation to students' perceived learning and satisfaction. Journal of Asynchronous Learning Networks 7(1): 68-88, 2003.

41. Collins, A., J. S. Brown and A. Holum. Cognitive apprenticeship: Making thinking visible. American Educator 15(3): 6-11, 38-46, 1991.

42. Feger S. and M. Zibit. Online Facilitation: Building Professional Knowledge Among Participants. Presented at Technology as an Agent of Teaching and Learning, San Francisco, 2006.

43. Conrad, D. University instructors' reflections on their first online teaching experiences. Journal of Asynchronous Learning Networks 8(2): 32-44, 2004.

44. Borko, H., B. M. Stecher and S. McClam. Artifact packages for measuring instructional practice: A pilot study. Comparative Analysis of Current Assessment and Accountability Systems, The Regents of University of California, 2003.

45. Lave, J. and E. Wenger. Situated Learning: Legitimate Peripheral Participation. Cambridge University Press, 1991.

46. Asbell-Clarke, J., E. Rowe, S. Leibowitz and P. Hubbard. Learning Science Online: A Descriptive Study of Online Science Courses for Teachers. Poster presented at AERA, San Francisco, 2006.

47. Asbell-Clarke, J. and E. Rowe. Learning Science Online: A Descriptive Study of Online Science Courses for Teachers. In press, to be released at http://www.terc.edu. 